\title{
PENGARUH DUKUNGAN SOSIAL DAN ATTACHMENT STYLE TERHADAP PERASAAN KESEPIAN PADA REMAJA YANG TINGGAL DI PANTI ASUHAN KHAZANAH KEBAJIKAN
}

\author{
Astrid Febry Nurdiani \\ Rachmat Mulyono \\ UIN Syarif Hidayatullah Jakarta \\ rachmat.mulyono@uinjkt.ac.id
}

\begin{abstract}
This research"s goal was to know the effect and contribution of social support, attachment style, gender, and charitable intitution towards lonliness on teenagers in Khazanah Kebajikan. 170 teenagers ( 79 male and 91 female) within 13-18 years old was used as sample using random sampling. Data analysis in this research was using multiple regression with SPSS 16.0. The result showed that there was a significant effect of emotional support, achievement support, instrumental support, informational support, link support, secure attachment style, fearful attachment style, preoccupied attachment style, dismissing attachment style, gender, and stayed for a long time towards loneliness. Then, from the coeficient regression of each $I V$, it was known that there was three IV that significantly effected loneliness, that was achievement support, link support, and fearful attachment style.
\end{abstract}

Keywords: Loneliness, Social Support, Attachment Style, Charitable Institution Teenagers

\begin{abstract}
Abstrak
Penelitian ini bertujuan untuk mengetahui pengaruh dan besarnya sumbangan dukungan sosial, gaya kelekatan, jenis kelamin, dan lama tinggal di panti asuhan terhadap perasaan kesepian pada remaja yang tinggal di Panti Asuhan Khazanah Kebajikan. Sampel berjumlah 170 remaja (79 laki-laki dan 91 perempuan) berusia 13-18 tahun yang dipilih dengan cara simple random sampling. Analisis data dalam penelitian ini menggunakan teknik regresi berganda dengan bantuan software SPSS 16.0. Hasil penelitian menunjukkan ada pengaruh yang signifikan secara bersama-sama dari dukungan emosional, dukungan penghargaan, dukungan instrumental, dukungan informasi, dukungan jaringan, secure attachment style, fearful attachment style, preoccupied attachment style, dismissing attachment style, jenis kelamin dan lama tinggal di panti asuhan terhadap perasaan kesepian. Kemudian, jika dilihat dari koefisien regresi masing-masing IV, diketahui bahwa hanya terdapat tiga IV yang signifikan pengaruhnya terhadap perasaan kesepian, yaitu dukungan penghargaan, dukungan jaringan, dan fearful attachment style.
\end{abstract}

Kata Kunci: Perasaan Kesepian, Dukungan Sosial, Gaya Kelekatan, Remaja Panti Asuhan 


\section{PENDAHULUAN}

Perasaan kesepian adalah respon terhadap dimilikinnya hubungan yang lebih sedikit dan lebih tidak memuaskan daripada yang diharapkan individu. Dari penelitian-penelitian mengenai kesepian, diketahui bahwa berdasarkan tingkat usia, remaja memiliki tingkat kesepian yang lebih tinggi daripada kelompok usia lainnya (Peplau \& Perlman, 1982). Peplau dan Perlman (1982) menjelaskan bahwa masa remaja merupakan masa dimana perasaan kesepian pertama kali muncul dan lebih sering dirasakan serta lebih mudah untuk dikenali oleh individu yang merasakannya. Hal ini dikarenakan, pada masa ini, remaja sering merasa kesulitan dalam menyesuaikan diri dengan perubahan dirinya, akibatnya mereka cenderung menyendiri sehingga merasa terasing, dan merasa tidak ada orang yang memperdulikannya, akhirnya merasa kesepian (Blos, dalam Ali dan Asrori, 2009).

Dari hasil penelitian Kutlu (2006), ternyata diketahui bahwa remaja yang tinggal di panti asuhan memiliki tingkat kesepian yang lebih tinggi daripada remaja yang tinggal dengan orang tuanya. Menurut Bicakci (2011) tempat dimana remaja tinggal, apakah di panti asuhan atau tinggal dengan keluarga juga ikut menentukan kemampuannya dalam berinteraksi dengan lingkungan. Remaja yang tinggal di panti asuhan diketahui memiliki kemampuan yang rendah akan adaptasi dan menjalin hubungan dengan rekan sebayanya, mereka cenderung kesulitan untuk mendapatkan teman baru, sehingga mudah merasa kesepian.

Bagi remaja panti asuhan, perasaan kesepiannya dapat disebabkan oleh kurang percaya terhadap orang lain, merasa malu dan minder sehingga cenderung menarik diri dalam bersosialisasi, merasa sedih karena tidak memiliki orang tua, dan tidak adanya teman untuk berbagi pikiran (Sudarman, 2010). Hal ini berarti sesuai dengan apa yang dijelaskan oleh Burger (Baron \& Byrne, 2005), dimana individu yang tidak menginginkan teman bukan orang yang kesepian, tetapi individu yang menginginkan teman dan tidak memilikinya lah yang disebut dengan individu yang kesepian.

Remaja yang tinggal di panti asuhan diharapkan untuk memperoleh kehidupan yang lebih baik. Kenyataannya, masih banyak panti asuhan di Indonesia yang masih kurang dalam memberikan pengasuhan bagi anak asuhnya (Sudrajat, 2008). Kebanyakan mereka hanya memfokuskan pada pemenuhan kebutuhan pendidikan dan juga material kebutuhan anak sehari-hari, sedangkan kebutuhan emosional anak kurang begitu diperhatikan. Selain itu, ketidakseimbangan rasio antara jumlah pengasuh dengan anak asuhnya dapat menyebabkan kualitas dan kuantitas perhatian, kasih sayang, dan dukungan yang diberikan pengasuh menjadi kurang maksimal. 
Padahal, dukungan sosial merupakan salah satu faktor yang amat penting bagi remaja panti asuhan agar mampu menyesuaikan diri dengan lingkungannya (Rahma, 2011). Semakin tinggi dukungan sosial yang diterima remaja panti, maka akan semakin tinggi pula kemampuan penyesuaian dirinya. Tidak adanya dukungan sosial, maka akan menimbulkan perasaan kesepian dan juga kehilangan pada remaja tersebut.

Fessman dan Lester (Hayati, 2010) menjelaskan bahwa dukungan sosial merupakan prediktor bagi munculnya perasaan kesepian. Hal ini sesuai dengan hasil penelitian yang dilakukan oleh Hayati (2010) yang menemukan adanya pengaruh yang negatif signifikan dari dukungan sosial terhadap perasaan kesepian. Jadi, semakin tinggi dukungan sosial yang diterima, maka kesepiannya akan semakin rendah, sebaliknya, semakin rendah dukungan sosial yang diterima maka akan semakin tinggi perasaan kesepiannya. Dari hasil penelitian tersebut diketahui juga bahwa sebesar $13,7 \%$ kesepian yang dirasakan individu itu dipengaruhi oleh dukungan sosial yang diterimannya.

Dukungan sosial merupakan perhatian, kasih sayang, bantuan, dan perasaan nyaman yang diberikan oleh seseorang/kelompok sehingga membuat individu merasa berarti dan diakui dalam lingkungannya. Remaja panti asuhan membutuhkan dukungan dari orang dewasa, yang dalam hal ini berarti pengasuh untuk membantunya mengatasi permasalahan yang dihadapi, terutama dalam mengatasi rasa kesepiannya (Sudarman, 2010). Pentingnya dukungan sosial yang diperoleh remaja yang tinggal di panti asuhan akan membuatnya merasa dicintai, diperhatikan, dan dihargai, serta diterima dalam lingkungan panti (Taylor, 2006).

Menurut Sarafino (1998) bentuk dukungan sosial yang diperoleh individu itu berupa dukungan emosional, penghargaan, informasi, instrumental, dan jaringan. Aliyah (2006) dalam penelitiannya menemukan bahwa terdapat hubungan yang negatif signifikan antara masing-masing jenis dukungan sosial yang diberikan, yaitu dukungan materi, emosional, penghargaan, informasi, dan integritas sosial/jaringan sosial dengan perasaan kesepian. Lebih jelasnya, semakin tinggi dukungan materi, emosional, penghargaan, informasi, dan jaringan yang diperoleh seseorang, maka akan semakin rendah perasaan kesepiannya.

Menurut Peplau dan Perlman (1982) faktor lain yang menyebabkan remaja merasa kesepian adalah berpisah dengan orang tua. Remaja yang tinggal di panti asuhan adalah anak-anak yang mengalami keterpisahan dengan orang tua atau keluarganya dikarenakan sebab-sebab tertentu. Sebelum mereka pindah atau tinggal di panti asuhan, mereka sudah menjalin ikatan emosional dengan figure attachment (figur yang melekat/dekat dengan individu) biasanya orang tua atau lebih sering Ibu. Akan tetapi setelah pindah dan harus tinggal di panti asuhan, remaja harus beradaptasi dengan lingkungan dan kondisi panti asuhan, dan juga harus menyesuaikan diri dengan peran pengasuh yang ada dalam panti. 
Perpisahan dengan figure attachment ini akan membuat remaja merasa kehilangan, sehingga akan menimbulkan perasaan kesepian (Weiss, dalam Peplau \& Perlman, 1982).

Perpisahan dengan figure attachment dapat mempengaruhi attachment style yang dimiliki individu. Attachment style adalah beberapa jenis gaya yang digunakan individu untuk mencari kedekatan dengan orang lain yang dianggap dapat memberikan rasa aman dan nyaman. Peplau dan Perlman (1982) menjelaskan bahwa cara terbaik untuk memahami kesepian yang dirasakan individu adalah dengan mempelajari attachment yang dimilikinya. Hal ini sesuai dengan hasil penelitian yang dilakukan oleh Erozkan (2011) yang menemukan bahwa attachment merupakan faktor yang dapat memprediksi munculnya perasaan kesepian.

Dari hasil penelitian tersebut diketahui bahwa sebesar 17,6\% faktor yang mempengaruhi kesepian itu dapat dijelaskan oleh attachment style yang dimiliki individu. Keempat attachment style, yaitu secure, fearful, preoccupied, dan dismissing diketahui berpengaruh terhadap perasaan kesepian. Fearful, preoccupied, dan dismissing attachment style memiliki korelasi yang positif signifikan dengan kesepian, sebaliknya secure attachment style berkorelasi secara negatif dengan kesepian. Artinya, individu yang fearful, preoccupied, dan dismissing akan cenderung lebih sering merasa kesepian daripada individu yang secure.

Di Indonesia, penelitian mengenai attachment style dengan kesepian pada remaja panti asuhan sudah pernah diteliti oleh Siregar (2005). Hasil dari penelitian tersebut menunjukkan bahwa tidak terdapat hubungan yang signifikan antara attachment dengan kesepian pada remaja panti asuhan. Hal ini berarti, hasil penelitian tersebut dengan penelitian sebelumnya (Erozkan, 2011) tidak sesuai. Beberapa hal yang diduga menyebabkan penelitian tidak signifikan yaitu penggunaan sampel yang kurang banyak, dimana sampelnya adalah remaja berusia 16-21 tahun yang hanya berjumlah 19 orang. Kemudian, hasil kategorisasi subjek berdasarkan attachment style-nya tidak seimbang, sehingga tidak dapat digeneralisasikan. Selain itu, attachment style yang digunakan dalam penelitian tersebut menggunakan teori Hazan dan Shaver yaitu, secure, avoidant, dan anxious attachment style. Dengan menggunakan teori tersebut, diketahui bahwa tidak ada perbedaan tingkat kesepian antara remaja yang memiliki tipe secure, avoidant, dan anxious. Maka dari itu, dalam penelitian ini, peneliti akan menggunakan teori yang berbeda dengan penelitian tersebut, yaitu dengan menggunakan empat attachment style yang dikembangkan oleh Bartholomew dan Horowitz, yaitu secure, fearful, preoccupied, dan dismissing attachment style.

Selain faktor dukungan sosial dan attachment style, peneliti juga akan menambahkan faktor demografi yang diduga juga berpengaruh terhadap perasaan kesepian. Faktor demografis yang diuji adalah jenis kelamin dan lama tinggal di panti asuhan. Untuk jenis kelamin, dari hasil penelitian (Akbag \& Imamoglu, 2010; Deniz, Hamarta, \& Ari, 2005; Hazer \& Boylu, 
2010) diketahui bahwa remaja laki-laki cenderung lebih tinggi perasaan kesepiannya daripada remaja perempuan. Sebaliknya, dalam penelitian lain (Gursoy \& Bicakci, 2006; Russell, 1996) diketahui bahwa remaja perempuan cenderung lebih tinggi perasaan kesepiannya daripada remaja laki-laki. Adanya perbedaan hasil dalam penelitian tersebut membuat peneliti tertarik untuk menguji kembali variabel jenis kelamin terhadap perasaan kesepian.

Selanjutnya, untuk lama tinggal di panti asuhan. Dari hasil penelitian Siregar (2005) diketahui bahwa remaja yang sudah lebih lama tinggal di panti lebih tinggi perasaan kesepiannya daripada remaja yang baru tinggal di panti. Hasil tersebut tidak sejalan dengan hasil penelitian Sudarman (2010), bahwa salah satu faktor yang mempengaruhi kesepian pada remaja yang tinggal di panti adalah sulit memahami nilai-nilai yang berlaku dalam lingkungan atau sulit beradaptasi dengan lingkungan baru. Ini berarti, seharusnya remaja yang baru tinggal di panti akan lebih tinggi perasaan kesepiannya daripada remaja yang sudah lebih lama tinggal di panti, karena mereka harus menyesuaikan diri dengan situasi dan kondisi panti asuhan. Bila remaja yang baru tinggal di panti asuhan tidak mampu menyesuaikan diri dengan kondisi panti, maka akan merasa kesepian.

\section{Perasaan kesepian}

Peplau dan Perlman (1982) menjelaskan bahwa perasaan kesepian merupakan pengalaman yang tidak menyenangkan yang terjadi ketika jaringan hubungan sosial seseorang berkurang, baik secara kuantitatif ataupun secara kualitatif. Berkurang secara kuantitatif maksudnya jumlah teman yang dimiliki tidak sesuai dengan yang diharapkan. Sedangkan secara kualitatif berarti kualitas hubungan yang dimiliki individu saat ini kurang memuaskan.

Baron, Branscombe, dan Byrne (2008) mendefinisikan kesepian sebagai keadaan emosional dan kognitif yang tidak menyenangkan karena menginginkan hubungan dekat tetapi tidak mampu mencapainya.

Berdasarkan definisi-definisi yang telah disebutkan di atas, maka definisi perasaan kesepian menurut peneliti adalah perasaan yang tidak menyenangkan yang disebabkan oleh berbagai hal, yaitu karena tidak adanya kedekatan dalam hubungan sosial, kurang memuaskannya hubungan sosial yang ada atau hubungan sosial yang tidak sesuai dengan harapan individu itu sendiri.

\section{Dukungan sosial}

Cobb, et al (Sarafino, 1998) mendefinisikan dukungan sosial sebagai bantuan yang diterima individu dari orang lain atau kelompok. Dukungan sosial menurut Sarafino (1998) mengacu pada kesenangan yang dirasakan, penghargaan akan kepedulian, atau membantu dan menerima pertolongan orang lain atau kelompok lain. Cobb (Sarafino, 1998) menjelaskan bahwa 
individu yang menerima dukungan sosial akan percaya bahwa dirinya dicintai, dihargai, dan merupakan bagian dari lingkungan sosialnya (keluarga atau komunitas organisasi) yang dapat menyediakan barangbarang, jasa, dan pertolongan ketika individu sedang mempunyai masalah.

Berdasarkan definisi-definisi yang telah dipaparkan di atas, jadi dapat disimpulkan bahwa dukungan sosial adalah bantuan yang diterima individu dari lingkungannya (orang lain) untuk mengatasi masalah yang dihadapinnya. Bantuan yang diterima dalam bentuk emosional, instrumental, informasi, dan bantuan lainnya sehingga individu yang menerima bantuan akan merasa dicintai, dihargai dan diakui keberadaannya oleh individu lain.

\section{Attachment Style}

Baron, Branscombe dan Byrne (2008) mendefinisikan attachment style sebagai derajat keamanan yang dialami dalam hubungan interpersonal. Baron dan Byrne (2005) menjelaskan bahwa attachment style yang dimiliki seseorang akan berpengaruh pada kemudahan individu dalam berteman, berinteraksi dengan orang lain, dan pada keberhasilannya dalam membina hubungan sosial.

Berdasarkan beberapa definisi dan penjelasan di atas, maka definisi attachment style menurut peneliti adalah beberapa jenis gaya yang digunakan individu untuk mencari kedekatan dengan orang lain yang dianggap dapat memberikan rasa aman dan nyaman. Jadi, attachment style ini merupakan dasar bagi individu untuk berinteraksi dan membangun hubungan interpersonal dengan orang lain.

\section{METODE}

Jumlah sampel dalam penelitian ini sebanyak 170 orang. Yang terdiri dari 79 remaja laki-laki dan 91 remaja perempuan berusia 13-18 tahun dan tinggal di Panti Asuhan Khazanah Kebajikan. Pengambilan sampel dalam penelitian ini menggunakan teknik probability sampling dengan cara simple random sampling.

Penelitian ini menggunakan tiga alat ukur. Instrumen pertama yang digunakan untuk mendeteksi perasaan kesepian diadaptasi dari UCLA loneliness scale version 3 yang terdiri dari 20 item (Russell, 1996). Dari hasil uji validitas dengan menggunakan analisis faktor konfirmatori (Confirmatory Factor Analysis /CFA), diketahui hanya 10 item yang valid, yaitu item nomor 2, 3, 4, 8, 11, 13, 14, 15, 17, dan 18 .

Instrumen penelitian kedua yang digunakan untuk mengukur dukungan sosial dibuat sendiri oleh peneliti berdasarkan jenis-jenis dukungan sosial yang dipaparkan oleh Sarafino (1998), yaitu dukungan emosional sebanyak 8 item, dukungan penghargaan sebanyak 9 item, dukungan instrumental sebanyak 9 item, dukungan informasi sebanyak 10 
item, dan dukungan jaringan sebanyak 9 item. Jadi total item pada skala dukungan sosial adalah 45 item. Dari hasil uji validitas diketahui bahwa, dari 45 item yang mengukur dukungan sosial, ternyata sebanyak 36 item valid dan sisanya 9 item didrop karena tidak valid, yaitu item nomor 16, 21, 27, 28, 30, 31, 37, 42, dan 45.

Instrumen penelitian ketiga yang digunakan untuk mengukur attachment style diadaptasi dari Relationship Scale Questionnaire (RSQ) yang dikembangkan oleh Griffin dan Bartholomew (Kurdek, 2002). Dalam bentuk aslinya, $R S Q$ terdiri dari 30 item, namun dalam penelitian ini, peneliti menambahkan lima item ke dalam skala sesuai dengan teori Bartholomew dan Horowitz (Polek, 2007). Sehingga total item pada skala attachment style adalah 35 item. Setelah dilakukan uji validitas, ternyata sebanyak 30 item valid dan sisanya 5 item didrop karena tidak valid, yaitu item nomor 6, 10, 17, 24, dan 32 .

\section{HASIL}

Sebagaimana yang telah dipaparkan pada bahasan sebelumnya, bahwa penelitian diberikan kepada 170 remaja Panti Asuhan Khazanah Kebajikan berusia 13-18 tahun. Adapun gambaran umum subjek penelitian dapat dilihat pada tabel 1 berikut ini:

Tabel 1

Gambaran Umum Subjek Penelitian

\begin{tabular}{llcc}
\hline Data Demografi & & $\boldsymbol{N}$ & $\mathbf{\%}$ \\
\hline Jenis kelamin & Laki-laki & 79 & 46,5 \\
& Perempuan & 91 & 53,5 \\
Usia & $13-15$ tahun & 67 & 39,4 \\
\multirow{2}{*}{ Pendidikan } & $16-18$ tahun & 103 & 60,6 \\
& SMP/MTs & 48 & 28,2 \\
& SMA/MA & 38 & 22,4 \\
Lama tinggal di panti asuhan & SMK & 84 & 49,4 \\
& $<1$ thn - 3 thn & 135 & 79,4 \\
& 4 thn - 6 thn & 25 & 14,7 \\
& 7 thn - 9 thn & 10 & 5,9 \\
\hline
\end{tabular}

Dari tabel di atas, jika dilihat dari jenis kelaminnya diketahui bahwa jumlah subjek perempuan lebih banyak daripada subjek laki-laki. Kemudian, jika dilihat dari usianya, remaja yang paling banyak dalam penelitian ini berada pada rentang usia 16-18 tahun, yang berarti sebagian besar subjek berada dalam taraf perkembangan remaja akhir. Selanjutnya, jika dilihat dari pendidikan saat ini, remaja yang paling banyak ada yang berada di tingkat SMK. Terakhir, bila dilihat dari lama tinggal di panti 
asuhan sebagian besar subjek sudah tinggal di panti asuhan dalam kurun waktu $<1-3$ tahun.

Selanjutnya, pada tabel 2 menampilkan hasil kategorisasi skor pada masing-masing variabel penelitian. Untuk mengkategorisasikannya, terlebih dahulu peneliti tetapkan norma skor dengan menggunakan nilai mean dan standar deviasi. Dalam penelitian ini, skor yang digunakan adalah true score, maka nilai mean dan standar deviasinya sudah disamakan, yaitu nilai mean= 50 dan standar deviasi $=10$. Jadi, dengan menggunakan nilai tersebut, jika nilai $\mathrm{n}<40$ masuk kedalam kategori rendah, jika nilai $40 \leq \mathrm{n} \leq 60$ maka masuk kedalam kategori sedang, dan jika nilai $n>60$ maka masuk ke dalam kategori tinggi.

\section{Tabel 2}

Kategorisasi Skor

\begin{tabular}{|c|c|c|c|c|c|}
\hline \multirow{2}{*}{ Dimensi } & \multirow{2}{*}{ Kategori } & \multicolumn{2}{|c|}{ Jenis Kelamin } & \multirow{2}{*}{$N$} & \multirow{2}{*}{$\%$} \\
\hline & & Laki-laki & Perempuan & & \\
\hline \multirow[t]{3}{*}{ Perasaan kesepian } & Rendah & 13 & 11 & 24 & 14,1 \\
\hline & Sedang & 55 & 63 & 118 & 69,4 \\
\hline & Tinggi & 11 & 17 & 28 & 16,5 \\
\hline \multirow[t]{3}{*}{ Dukungan emosional } & Rendah & 11 & 8 & 19 & 11,2 \\
\hline & Sedang & 54 & 68 & 122 & 71,8 \\
\hline & Tinggi & 14 & 15 & 29 & 17,1 \\
\hline \multirow[t]{3}{*}{ Dukungan penghargaan } & Rendah & 11 & 12 & 23 & 13,5 \\
\hline & Sedang & 58 & 63 & 121 & 71,2 \\
\hline & Tinggi & 10 & 16 & 26 & 15,3 \\
\hline \multirow[t]{3}{*}{ Dukungan instrumental } & Rendah & 11 & 13 & 24 & 14,1 \\
\hline & Sedang & 48 & 66 & 114 & 67,1 \\
\hline & Tinggi & 20 & 12 & 32 & 18,8 \\
\hline \multirow[t]{3}{*}{ Dukungan informasi } & Rendah & 13 & 13 & 26 & 15,3 \\
\hline & Sedang & 54 & 55 & 109 & 64,1 \\
\hline & Tinggi & 12 & 23 & 35 & 20,6 \\
\hline \multirow[t]{3}{*}{ Dukungan jaringan } & Rendah & 12 & 11 & 23 & 13,5 \\
\hline & Sedang & 54 & 64 & 118 & 69,4 \\
\hline & Tinggi & 13 & 16 & 29 & 17,1 \\
\hline \multirow[t]{3}{*}{ Secure attachment style } & Rendah & 11 & 9 & 20 & 11,8 \\
\hline & Sedang & 61 & 61 & 122 & 71,8 \\
\hline & Tinggi & 7 & 21 & 28 & 16,5 \\
\hline \multirow[t]{3}{*}{ Fearful attachment style } & Rendah & 9 & 13 & 22 & 12,9 \\
\hline & Sedang & 54 & 60 & 114 & 67,1 \\
\hline & Tinggi & 16 & 18 & 34 & 20 \\
\hline
\end{tabular}




\begin{tabular}{llccccc}
\hline \multirow{2}{*}{ Dimensi } & \multirow{2}{*}{ Kategori } & \multicolumn{2}{c}{ Jenis Kelamin } & \multirow{2}{*}{ N } & \% \\
& & Laki-laki & Perempuan & & \\
\hline Preoccupied attachment style & Rendah & 8 & 14 & 22 & 12,9 \\
& Sedang & 60 & 62 & 122 & 71,8 \\
& Tinggi & 11 & 15 & 26 & 15,3 \\
Dismissing attachment style & Rendah & 11 & 19 & 30 & 17,6 \\
& Sedang & 53 & 60 & 113 & 66,5 \\
& Tinggi & 15 & 12 & 27 & 15,9 \\
\hline
\end{tabular}

Dari tabel 2 di atas, dapat dilihat bahwa, untuk skor perasaan kesepian, remaja perempuan cenderung lebih tinggi kesepiannya daripada remaja laki-laki. Berikutnya untuk dukungan sosial, dapat dilihat bahwa dukungan paling rendah yang diperoleh remaja panti asuhan adalah dukungan penghargaan dan dukungan jaringan. Namun, jika dilihat dari jenis kelaminnya, diketahui bahwa remaja perempuan lebih rendah dukungan penghargaan dan dukungan instrumentalnya. Sedangkan, remaja laki-laki lebih rendah dukungan emosional dan dukungan jaringannya.

Terakhir, untuk attachment style dapat dilihat bahwa remaja panti asuhan paling banyak memiliki fearful attachment style. Jika dilihat dari jenis kelaminnya, diketahui bahwa remaja perempuan lebih tinggi secure attachment style-nya daripada laki-laki. Namun, pada remaja laki-laki diketahui bahwa dismissing attachment style-nya lebih tinggi daripada perempuan.

Selanjutnya, peneliti akan menguji hipotesis penelitian dengan menggunakan teknik analisis berganda dengan bantuan software SPSS 16.0. Langkah pertama, peneliti melihat besaran $R$ square untuk mengetahui berapa persen (\%) varians DV yang dijelaskan oleh IV. Adapun hasilnya dapat dilihat pada tabel 3 berikut ini:

Tabel 3

R Square

\begin{tabular}{lllll}
\hline Model & R & R Square & Adjusted R Square & $\begin{array}{l}\text { Std. Error of the } \\
\text { Estimate }\end{array}$ \\
\hline 1 & $.411^{\mathrm{a}}$ & .169 & .111 & 9.42969 \\
\hline
\end{tabular}

a. Predictors: (Constant), LTP, Secure, JK, Instrumental, Emosional, Fearful, Dismissing, Jaringan, Informasi, Preoccupied, Penghargaan

Berdasarkan tabel di atas, dapat diketahui bahwa dengan menggunakan seluruh IV terhadap DV, diperoleh nilai $\mathrm{R}$ square 0,169. Artinya, proporsi varians dari perasaan kesepian yang dijelaskan oleh seluruh IV hanya sebesar $16,9 \%$, sedangkan $83,1 \%$ sisanya dipengaruhi oleh variabel lain di luar penelitian ini. 
Langkah kedua peneliti melihat apakah seluruh IV berpengaruh secara signifikan terhadap DV, yaitu perasaan kesepian. Adapun hasilnya dapat dilihat pada tabel 4 berikut ini:

\section{Tabel 4}

Anova

\begin{tabular}{lllllll}
\hline \multicolumn{2}{l}{ Model } & $\begin{array}{l}\text { Sum of } \\
\text { Squares }\end{array}$ & Df & \multicolumn{2}{c}{ Mean Square F } & Sig. \\
\hline 1 & Regression & 2850.799 & 11 & 259.164 & 2.915 & $.002^{\mathrm{a}}$ \\
& Residual & 14049.201 & 158 & 88.919 & & \\
& Total & 16900.000 & 169 & & & \\
\hline
\end{tabular}

a. Predictors: (Constant), LTP, Secure, JK, Instrumental, Emosional, Fearful, Dismissing, Jaringan, Informasi, Preoccupied, Penghargaan

b. Dependent Variable: Kesepian

Dari tabel di atas, jika melihat kolom paling kanan (kolom sig.), diketahui bahwa nilai sig $=0,002<0,05$, maka hipotesis nihil dalam hipotesis mayor yang menyatakan tidak ada pengaruh yang signifikan dari seluruh IV terhadap DV, yaitu perasaan kesepian ditolak. Artinya, ada pengaruh yang signifikan dari dukungan emosional, dukungan penghargaan, dukungan instrumental, dukungan informasi, dukungan jaringan, secure attachment style, fearful attachment style, preoccupied attachment style, dismissing attachment style, jenis kelamin, dan lama tinggal di panti asuhan terhadap perasaan kesepian pada remaja yang tinggal di panti asuhan khazanah kebajikan.

Langkah ketiga adalah menjawab hipotesis minor, yaitu melihat signifikan atau tidaknya koefisien regresi dari masing-masing IV. Apabila nilai signifikansi yang terdapat pada kolom paling kanan (kolom sig.) menunjukkan angka dibawah 0,05 , maka koefisien regresi yang dihasilkan signifikan pengaruhnya terhadap DV dan sebaliknya. Adapun hasilnya dapat dilihat pada tabel 5 berikut ini: 


\section{Tabel 5}

Koefisien Regresi

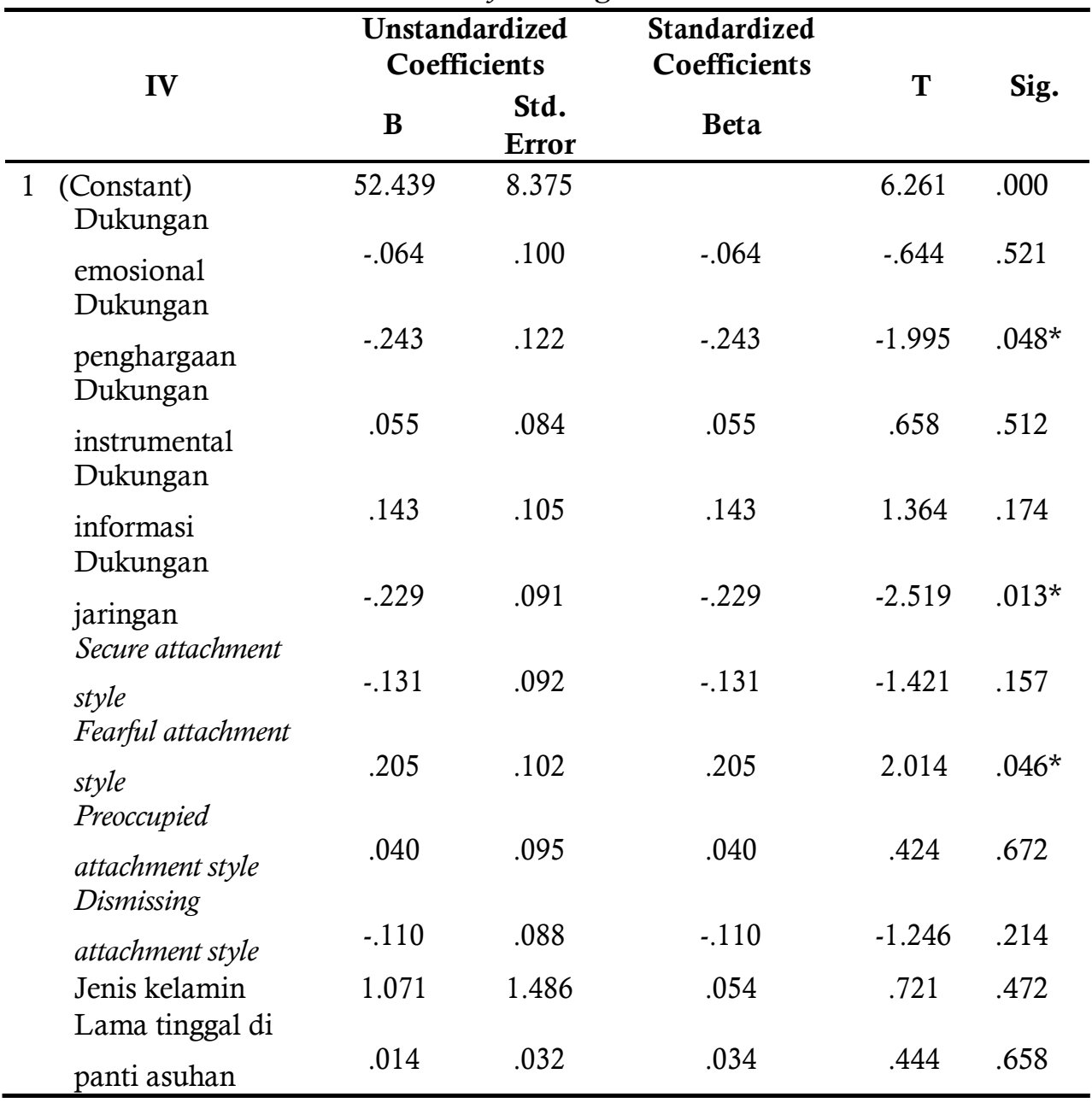

Keterangan: tanda $\left({ }^{*}\right)$ menunjukkan variabel yang signifikan

Berdasarkan tabel di atas, dapat diketahui bahwa koefisien regresi IV yang signifikan adalah dukungan penghargaan, dukungan jaringan, dan fearful attachment style. Sedangkan, sisa lainnya tidak signifikan.

\section{DISKUSI}

Secara umum dapat diambil dua kesimpulan. Pertama, bahwa ada pengaruh yang signifikan secara bersama-sama dari dukungan emosional, dukungan penghargaan, dukungan instrumental, dukungan informasi, dukungan jaringan, secure attachment style, fearful attachment style, preoccupied attachment style, dismissing attachment style, jenis kelamin, dan lama tinggal di panti asuhan terhadap perasaan kesepian pada remaja yang tinggal di panti asuhan khazanah kebajikan dengan proporsi varians sebesar 16,9\%. Artinya, bervariasinya perasaan kesepian yang dijelaskan oleh seluruh IV 
yang telah dipaparkan diatas hanya sebesar $16,9 \%$, sedangkan $83,1 \%$ sisanya dipengaruhi oleh variabel lain di luar penelitian ini.

Kedua, dari sebelas IV yang diuji, ternyata hanya terdapat tiga IV yang berpengaruh secara signifikan terhadap perasaan kesepian, yaitu dukungan penghargaan, dukungan jaringan, dan fearful attachment style. Dukungan penghargaan memberikan pengaruh yang signifikan secara negatif terhadap perasaan kesepian. Artinya, semakin tinggi dukungan penghargaan pada remaja panti asuhan khazanah kebajikan, maka semakin rendah perasaan kesepiannya. Dukungan penghargaan ini amat penting diberikan kepada remaja yang merasa kesepian, mengingat salah satu karakteristik yang dimiliki individu yang kesepian adalah merasa tidak berharga (Jones, dalam Peplau \& Perlman, 1982). Remaja yang merasa tidak berharga akan mudah merasa ditolak dan tidak diterima orang lain, selain itu mereka kurang memiliki rasa percaya diri untuk membangun hubungan sosial dengan orang lain sehingga muncul perasaan kesepian (Dhal, et al, 2007). Maka dari itu, dengan memperoleh dukungan penghargaan, remaja panti asuhan yang kesepian akan lebih rendah tingkat kesepiannya dan mampu menghargai dirinya dan hidupnya sehingga akan menjadikan hidupnya lebih berguna, baik untuk dirinya sendiri, orang lain, dan lingkungannya.

Selanjutnya, dukungan jaringan juga memberikan pengaruh yang signifikan terhadap perasaan kesepian. Dukungan jaringan memberikan pengaruh yang signifikan secara negatif terhadap perasaan kesepian. Artinya, semakin tinggi dukungan jaringan pada remaja panti asuhan khazanah kebajikan, maka semakin rendah perasaan kesepiannya. Bagi remaja panti asuhan khazanah kebajikan, dukungan jaringan yang diperoleh dari kakak asuh dan teman-teman sesama panti dapat membuatnya merasa diterima di panti asuhan. Hal ini mungkin dikarenakan kesamaan latar belakang, seperti sudah tidak memiliki orang tua lengkap atau kesamaan lain yang membuat mereka merasa berada dalam keadaan senasib, sehingga dapat saling mengerti perasaan satu sama lain.

Selanjutnya fearful attachment style memberikan pengaruh yang signifikan secara positif terhadap perasaan kesepian. Artinya, semakin tinggi fearful attachment style pada remaja panti asuhan khazanah kebajikan, maka semakin tinggi perasaan kesepiannya. Dari hasil skor, diketahui bahwa fearful merupakan attachment style paling tinggi yang dimiliki remaja panti asuhan khazanah kebajikan. Tingginya fearful attachment style ini mungkin dikarenakan remaja panti asuhan pernah memiliki pengalaman ditinggal oleh orang-orang terdekatnya (salah satu/ kedua orang tua/ orang lain yang dianggap spesial), sehingga karena pengalaman itulah mereka takut suatu saat akan terulang kembali dan lebih memilih untuk tidak terlalu dekat dengan orang lain. Maka dari itu lah mereka cenderung menghindari hubungan yang akrab sehingga mudah merasa kesepian. 
Ada beberapa saran yang bisa diajukan untuk peneliti berikutnya. Pertama, hasil penelitian menunjukkan bahwa seluruh IV memberikan sumbangan varians sebesar $16,9 \%$ terhadap perasaan kesepian. Sedangkan, sisanya sebesar $83,1 \%$ dapat dipengaruhi oleh variabel lain. Oleh sebab itu, disarankan bagi penelitian selanjutnya agar meneliti variabel-variabel lain yang mempengaruhi perasaan kesepian, seperti adjustment, self esteem, friendship and family relationship, subjective well-being, kepribadian extraversion dan neuroticism dan faktor demografi seperti usia dan tingkat pendidikan.

Saran kedua, untuk pengasuh diharapkan untuk meningkatkan dukungan penghargaan dan jaringan agar dapat mengurangi perasaan kesepian pada remaja panti asuhan. Dukungan tersebut dapat diberikan dalam bentuk pujian ketika anak asuh melakukan tugas dengan baik, mendukung ide-ide anak asuh yang dapat membuatnya menjadi pribadi yang lebih baik, dan memberikan semangat ketika mereka mengalami kegagalan. Terakhir, bagi remaja panti asuhan disarankan untuk meningkatkan rasa percaya pada orang lain dan tidak menutup diri dalam berteman agar dapat melupakan masa lalunya sehingga tidak terus merasa kesepian.

\section{DAFTAR PUSTAKA}

Akbag, M \& Imamoglu, S. E. (2010). The prediction of gender and attachment styles on shame, guilt, and loneliness. Journal education science, 10(2), 669-682.

Baron, R. A. \& Bryne, D. (2005). Psikologi sosial, Jilid II (Terj. Ratna Djuwita). Jakarta: Erlangga.

Baron, R. A., Branscombe, N. R., \& Byrne, D. (2008). Social psychology (12 ed). Boston: Pearson Education, Inc.

Bicakci, M. Y. (2011). Analysis of social adaptation and friend relationships among adolescents living in orphanage and adolescenst living with their family. Social and natural sciences journal. 3, 25-29.

Deniz, M. E., Hamarta, E., \& Ari, R. (2005). An investigation of social skills and loneliness levels of university student with respect to their attachment styles in a sample of turkish students. Journal social behavior and personality, 33(1), 19-32.

Dhal, A., Bhatia, S., Sharma, V., \& Gupta, P. (2007). Adolescent selfesteem, attachment and loneliness. Journal indian assoc. child adolesence mental health. 3(3), 61-63.

Erozkan, A. (2011). The attachment styles bases of loneliness and depression. Journal of psychology and counseling, 3(9), 186-193.

Gursoy, F. \& Bicakci, M, Y. (2006). A study on the loneliness level of adolescents. Journal of qafqaz university, 18, 140-146.

Hayati, S. (2010). Pengaruh dukungan sosial terhadap kesepian. Skripsi. Medan: Universitas Sumatera Utara. 